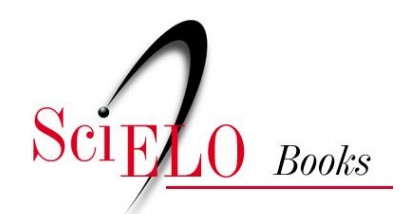

\title{
O popular e seus muitos...
}

\author{
Geralda Medeiros Nóbrega
}

NÓBREGA, GM. O popular e seus muitos... . In: Hermilo Borba Filho: Memória de resistência e resistência da história [online]. Campina Grande: EDUEPB, 2015, pp. 77-116. ISBN 978-85-7879334-0. Available from SciELO Books $<$ http://books.scielo.org $>$.

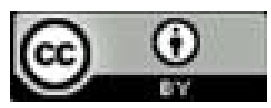

All the contents of this work, except where otherwise noted, is licensed under a Creative Commons Attribution $\underline{4.0 \text { International license. }}$

Todo o conteúdo deste trabalho, exceto quando houver ressalva, é publicado sob a licença Creative Commons Atribição 4.0.

Todo el contenido de esta obra, excepto donde se indique lo contrario, está bajo licencia de la licencia $\underline{\text { Creative }}$ Commons Reconocimento 4.0. 


\section{O POPULAR E SEUS MUITOS...}

"A literatura bem comportada prefere desconhecer a cultura de resistência e se refugia em campos onde os valores do homem atual são relegados a um plano de masturbação intelectual."

Hermilo Borba Filho

Denúncia, crítica, sátira, humor ou outras modalidades de insatisfação prescrevem neste autor uma criação ficcional que desenvolve "a quota de humanidade na medida em que nos torna mais compreensivos e abertos para a natureza, a sociedade, o semelhante" (CANDIDO, 1989, p.117). A variante do adágio "a justiça tarda mas não falha" (conservando a mesma estrutura fonossintática), "a justiça tarda mas não falta" (SDC, p.82) coloca em evidência a verve irônica de Borba Filho como uma marca usual de sua literatura. Pondo o leitor em contato com Zoroastro Paralelo Paranhos da Penha, da mais fina sociedade local, num jogo de causa/consequência, narra a sua queda, ocasião em que destaca a corrupção política e os interesses escusos do poder constituído:

Zoroastro Paralelo chefiava uma quadrilha de contrabandistas de aguardente, de quebra outra de ladrão de cavalo, e mais ainda que fazia parte 
de uma associação para tirar deste mundo as pessoas que os associados acharem desagradáveis, sendo que parece vice-presidente da sapientíssima entidade, tudo porque houve mudança na política, outro governador no Estado pretendendo aquelas regalias para seu apaniguado de nome Tomásio Guarulhos [...] antigo matador nos pagos da Paraíba, coisa que queria dizer mais eficiência (SDC, p.81-2).

Borba Filho, pois, sabe tirar proveito da organização literária adequada, emprenhando sua literatura como instrumento consciente de desmascaramento e focaliza no seu universo literário aspectos que deveriam reger a ética política. $O$ autor singulariza este empenho através do seu projeto literário e, neste contexto, particulariza esta perspectiva através da personagem Zoroastro Paralelo; o autor/ narrador universaliza o seu compromisso com a arte, como figurante de uma luta virtual pela moralização dos costumes. Num conto de título ameno, "Retratos e flores" (SDC, p.79-85), criticamente, dribla a própria criatividade, inserindo aspectos outros, como o suicídio da personagem, pois "Zoroastro Paralelo resolvera viajar com uma bala nos miolos, deixando as gêmeas Aglacê e Batilda na mais negra orfandade" (SDC, p.83). Esta história com um apelo ao maravilhoso, pois as gêmeas que dormiam na larga cama "que fora palco das fornicações conjugais de Zoroastro Paralelo" (SDC, p.84), foram enlaçadas por uma gitirana que afrouxou o abraço após dois meses, quando se contacta, posteriormente, com um discurso marcado por construções paralelísticas que enfatizam aspectos do real, gerando um contexto inverossímil dinâmico. Contribui para isto o uso dos polissíndetos, o emprego reiterativo do infinitivo, associado ao pretérito perfeito, determinando, gradativamente, um clima de desvanecimento: "Elas se levantaram e andaram e descobriram que podiam viver sem comer sem beber sem falar sem dormir sem sonhar, foram aos jarros, 
mudaram as flores e a água podre e viram que estavam com bem cem anos a mais" (SDC, p.85).

Vale ressaltar que, neste texto, assim como na maioria dos contos, "a esfera erudita e a popular trocam influência de maneira incessante, fazendo da criação literária e artística um fenômeno de vasta intercomunicação" (CANDIDO, 1989, p.123), em que a semiose dos códigos utilizados ressalta o dado popular, através da construção discursiva:

Mestre Lindolfo já nasceu mestre, das artes e das profissões, pintor e barbeiro, letrista, flautista edecetera coisa e tal, e por isto não era de estranhar que aos vinte anos, a paleta numa mão e o pincel na outra, defronte da tela, passinhos para frente passinhos para trás, ventas quase coladas ao quadro tal a miopia precoce, executasse durante dias e semanas a sua obra-prima (SDC, 1989, p.79).

Em Borba Filho, a junção da cultura erudita com a popular permite destacar a segunda, pois os dois níveis de cultura, antes se completam, servindo um como apanágio do outro, na integração de uma visão de mundo popular, submetida a uma perspectiva de literatura erudita. O sentido nem sempre será o mesmo, pois o reaproveitamento das fontes populares tem objetivos determinados, inferências que se alicerçam no próprio texto hermiliano, quando se está em constante relação com a contestação, a crítica, e o humor, conforme já fiz referência e, ainda, outros recursos, da ficção deste autor, que implantam a cultura de resistência.

Embora não distinga cultura de povo e cultura popular, como alguns estudiosos tentam fazê-lo, Borba Filho, alicerçado neste veio da cultura, enfatiza a resistência, através do compromisso com um fazer literário que traz à tona uma literatura insolente, pelos temas abordados e pela linguagem desabrida. Torna-se, pois, necessário 
averiguar como esta cultura resgata os valores contidos na concepção do universo popular. Borba Filho, empenhando-se em destacar os matizes culturais de suas narrativas, impede que códigos, produtos culturais e senso comum da estrutura de mundo do povo sejam soterrados no emaranhado de uma cultura dependente.

No autor da trilogia de contos, harmonizam-se todos os ingredientes da resistência em "suas manifestações ficcionais, poéticas e dramáticas de acordo com os seus impulsos, os seus sentidos, as suas normas, a fim de fortalecer em cada um a presença e atração deles" (CANDIDO, 1989, p.113). Assim, cabe ao escritor expressar sua posição no que se refere à crítica num âmbito artístico, que capta as mazelas do mundo real. Borba Filho, comprometendo-se, liberta-se de uma "literatura bem comportada", evitando, deste modo, "a masturbação intelectual", conforme evidencio na epígrafe.

O autor, que diz não acreditar em palavrão, pois só conhece palavras, "com o seu peso, a sua medida e o seu valor", evidencia: "Não tenho vergonha das palavras e as emprego exatamente para, inclusive num sentido popular puro designar as partes nobres do homem e da mulher, por exemplo, são estas palavras insubstituíveis como são na conversa, na raiva, no ato de amor" (CIRANO, 1981, p.52).

A afirmação do escritor pode ser ilustrada com o exemplo abaixo, situação em que o nível da obscenidade está respaldado pelo conteúdo pornográfico, sobressaindo o tom lúdico: "disseram e contaram, viúvo mandando as filhas morar na cidade, enquanto entrava dia e saía dia e ele descabaçando a piva duas vezes por dia no apreceio vermelho em volta do cipa" (GEP, p.69).

Esta perspectiva da metalinguagem em Borba Filho é recurso que difunde a cultura de resistência por ele apregoada, com a força expressiva que adquire a descrição da tortura no conto "A anunciação" (GEP, p.117-127). O nível de ambiguidade, as construções paralelísticas, o tom minucioso e reiterativo, assim como a polarização da linguagem e o emprego de palavrões, representativos do baixo corporal, dão a 
exata medida de uma cultura, resistente pela sua própria natureza, pela sua consistência e pelo estilo contundente:

Guará sabia que podia fazer, mas não agüentou mais de quarenta e oito horas. Que agüentou, agüentou: pau na marra, pau na bunda, cacetada nos penduricalhos, cacete no ventoso, extração de dentes e de pentelhos, arranco da unha do indicador da destra e quebra do dedo mínimo da sinistra, novamente cacete na panasqueira (GEP, p.125).

A cultura de resistência vista pelo autor como engajamento nas lides do popular, oposição à cultura dependente, insubordinação ao imperialismo cultural, resgate da liberdade da dignidade do Homem, combate à intolerância sob qualquer aspecto, é uma cultura de libertação. Libera a forma de expressão, de pensamento e de criação, fazendo da escritura elemento de instigação que capta vivências do mundo real e as transfigura, no universo literário, ao mesmo tempo em que resgata os dados da cultura popular, no afã de manter viva a tradição. Por isso, é pertinente aproximar deste contexto a posição de Bosi (1992), referindo-se à cultura de resistência. Para ele, também, faz parte desta cultura "o resgate da lembrança que alimenta o sentimento do tempo e o desejo de sobreviver" (BOSI, 1994, p.366).

O resgate da lembrança corresponde, na ficção hermiliana, ao afã de manter viva a memória coletiva e o desejo de sobreviver implica não só em preservar o passado, mas também em investir no futuro, visão utópica de mudanças e transformações do mundo real: “é esperar que a ditadura passe e chegue a democracia [...] ele se candidataria, depois de trinta anos a edilidade precisaria de outras mãos, mãos civis" (SDC, p.44-45). 


\section{Discernimento da cultura popular em Borba Filho}

A cultura popular remete a uma determinada realidade brasileira, pois num país cheio de contradições vitais, onde as estruturas econômicas, políticas e culturais não foram ainda devidamente definidas, a sua cultura representa um fenômeno cheio de imprecisões. Considerando que a arte popular é coisa viva, não se podem perder de vista as transformações por que passa a cultura popular, embora haja sobre os aficionados desta cultura a tentativa de devolver ao povo as formas artísticas por ele criadas. Este foi o empenho de Borba Filho ao longo de sua trajetória literária, teatral ou ensaística, principalmente naquilo que se relaciona às fontes de cultura do povo, à sua análise e ao seu aproveitamento. O narrador hermiliano concentra, num pequeno trecho, elementos diferenciados que caracterizam a visão popular. O clima de religiosidade, o nível de linguagem, as referências à área da comida e da bebida, a ornamentação do ambiente, os instrumentos musicais, tudo converge para respaldar a concepção de mundo popular. É o que Wagner (2010) chama a atenção quando quer destacar as representações do que é preciso discernir: “Todas as simbolizações convencionais, na medida em que são convencionais, têm a propriedade de 'representar' ou denotar algo diferente delas mesmas. Essa é a noção tradicional de 'símbolo', empregada por Charles Sanders Peirce e outros" (WAGNER, 2010, p.84). Complementando, diria com Peirce que "um símbolo é um signo que perderia o caráter que o torna signo, se não houvesse interpretante" (PEIRCE, 1975, p.131). O interpretante, pois, transforma-se em novo signo e assim por diante, ad infinitum.

Borba Filho é um empreendedor da cultura e o faz, aproveitando o já existente, o que respalda a tradição, na linha peirceana, permitindo que o interpretante sígnico alce voo para indicar que nada parece estável, o que se constitui em Borba Filho como marca de seu estilo. 
[...] siá Claudina culatrão, mais do que ancha, preparou sua novena puxada a capricho com flores artificiais, incensos, velas novas, para depois um grão-taurus da maior sustança rebatido com um capado, tudo molhado a quinado, cachaça e capilé e agradado com uma orquestrinha de pau e corda para as danças devotadas a Excelsa (GEP, p.110).

O autor, encaixando-se na cultura popular tradicional, resultante de uma aquisição de aspirações, não se realiza apenas no plano da realidade comum, mas também no plano da imaginação artística. Essa visão tradicional, mesmo apresentando certas reservas em alguns estudiosos, é a visão de cultura popular mais próxima do que é defendido por Borba Filho, como está em Fávero (1983) que defende na cultura o popular pelo popular. Introduzindo na sua literatura o povo e o elemento popular como tema, motivo, personagem, entre outros elementos, abole a distância entre observador (Borba Filho, enquanto autor) e o objeto de sua apreensão como vivência literária (o povo), desenvolve um discurso sobre o povo ou um discurso do povo, na esteira do que é desenvolvido por Mouralis (1982).

A cultura popular pode-se concretizar de formas diferentes, servindo sempre aos mesmos propósitos. Em Borba Filho, afora a captação da concepção de arte popular, o autor compromete-se, no plano literário, a resgatar formas artísticas que estão nas raízes do povo, o que pode ser compreendido tanto como instrumento de conservação, como de transformação social. Desse modo, coloca-se a cultura em termos de problema social para o intelectual afeito ao trabalho de cultura popular, contexto que se integra à ficção hermiliana porque "o popular significa, portanto, a transfiguração expressiva de realidades vividas, conhecidas, reconhecíveis e identificáveis, cuja interpretação pelo artista e pelo povo coincidem" (sic), segundo defende Chauí (1990, p.88), que parece identificar-se com o contexto hermiliano, como pode ser ilustrado com o conto "Os tropeiros do céu" (SDC, p.2741). O conto narra a história de uma companhia de teatro ambulante, 
em que Jésu, o ator principal é também o dono da companhia. As encenações giram em torno de Jesus Cristo, mas a centralização na cultura popular abarca variadas modalidades, desde a maneira de encarar o sexo, passando pelo jogo de sueca, cenas de milagres, até o aproveitamento da oralidade. Exemplifico com um texto em que a visão popular se destaca através de canções ao mesmo tempo em que o narrador demonstra conhecer a arte cênica:

[...] ele, que em tudo era que pensava, em tudo
mandava, não somente como Cristo Jesus, mas
como empresário, primeiro ator, figurinista, cenó-
grafo, ensaiador, só não dizia que era compositor
por que as músicas do espetáculo eram arranjos
de velhas canções populares da região, que o povo
gostava, como O Tatu Subiu no Pau para a hora da
cruz ou Me Leva me Leva seu Rafael para a fuga
para o Egito ou o Não Não Quero Mais Teus Beijos
para a hora da traição de Judas, em toque lento e
penoso (SDC, p.30-31).

Chauí, no entanto, chama a atenção para o fato de se pensar na História sob o ângulo regressivo dos românticos, contexto em que a cultura popular passa a ser entendida como a boa origem perdida. Ao mesmo tempo, a autora indica um caminho em que "a prática da Cultura Popular pode tomar a forma de resistência e introduzir 'a desordem' na ordem, abrir brechas, caminhar pelos poços e pelos interstícios da sociedade brasileira [...]” (CHAUÍ, 1989, p.178).

Tudo isto foi posto em prática por Borba Filho, na retomada de motivos, vigentes na cultura popular, transfigurados de modo a estabelecer o conflito numa estrutura que se compromete, sem ficar indiferente ao Homem em suas necessidades de paz, justiça e liberdade. Posso inferir que este autor tenha compreendido que "[...] pensamentos, palavras e atos de uma cultura de resistência ainda não vencida pela força da desintegração ‘seja' um tênue lume de esperança 
que bruxuleia no termo deste percurso" (BOSI, 1994, p.383). No conto "O Mateus" (AMS, p.51-53), por exemplo, o autor enfatiza os dados da cultura popular com elementos sexuais, ao mesmo tempo em que denuncia o crime perpetrado contra a personagem Besuntado, ator do Bumba meu Boi. No trecho ilustrativo, o narrador utiliza o discurso do espetáculo popular, já referenciado, o que envolve o leitor no encadeamento da escrita em que "de todo imóvel", "já não era", "tinha sido", "passara-se", "descansando", "uma chaga", são imagens eufemísticas da morte, em meio ao discurso do espetáculo:

[...] o Besuntado chamado, Mateus afamado, negro danado você diz que sopra o fole, tome o fole pra soprar, Besuntado deitado mas de todo imóvel, foi tocar com a ponta do pé branco, o dedo grande do pé branco e ver Besuntado, Mateus afamado, do fole negro danado, já não era, tinha sido, passara-se, os braços ao longo do corpo, o sexo afamado, negro danado, descansando, na altura do coração uma chaga (AMS, p.53).

Os contos hermilianos quase sempre são adequados à maneira de sentir e de pensar do povo. Fugindo ao escapismo e definindo-se como um escritor que não pode viver fora de sua época, diz o autor:

Por que, então, não praticar um ato político com a literatura, desde que este ato tenha como finalidade, não a solução do problema, que aí voltaríamos ao romance-tese, mas a exposição do conflito? Acho mesmo que escrever, nos dias de hoje, já implica um compromisso político, qualquer que seja a tendência do escritor, de tal modo estamos envolvidos neste caminho da humanidade (ENTREVISTA, 1974, p.6, informação verbal). 
É em contato com a cultura popular que o escritor pode perceber que "há toda uma descoberta da dialética das relações sociais, entre aparência e essência, singular e universal que revoluciona a criação [...] artística" (IANNI, 1983, p.118), o que possibilita a Borba Filho manter-se coeso em torno de um veio da cultura cuja representatividade pode respaldar um projeto literário em sintonia com a cultura popular, o que pode ser observado no trecho abaixo, em que a personagem retirada do mundo real atua como ator, tal qual desenvolve a sua arte no espetáculo popular do mamulengo:

\begin{abstract}
[...] mandei um bilhete para minha noiva querida Bernarda é impossível te ver-te hoje Cheiroso Dorabela e Companhia Limitada assim ela ficou sabendo que eu estou no trabalho pegado que está livre que se quiser aceitar só que vai se arrepender e ela sabe disto cipó de boi ficou foi pra estas coisas mesmo e vós doutor de leis vais me desculpar que ainda tenho uma boa lapada de caminho [...] tenho de colocar meus perfumes e me divertir com os meninos [os bonecos] que estão acochados no fundo dessa mala doidos pra vadiar [...] (SDC, p.101).
\end{abstract}

Ainda estou com Ianni falando em cultura popular, para destacar que "[...] há um mundo de contos, histórias, e causos dos vários tipos, relatos e fantasias, que expressam uma tremenda riqueza na maneira de ver, de pensar, de articular, o que é o universo social, cultural, natural, etc., dessa gente" (IANNI, 1983, p.117):

Não tem arco-íris? Tem. 0 arco-íris não puxa água pelas nuvens? Pois: quando ele puxa, arrasta com tudo, é pedra, é tudo. A pedra fica nas nuvens. Quando o calor lá em cima é grande, dá o trovão, solta a pedra da nuvem. Aquilo vem numa 
velocidade que só vendo e o trabalho do ar vai desgastando ela até que fica um gume feito uma foice. É bater numa árvore, abre. Lá na fazenda do meu pai, eu já vi muito dessas pedras, é feito uma pedra de mó, de amolar, sabe? (SDC, p.134).

Ecléa Bosi (1986, p.84) complementa o pensamento de Ianni quando afirma que a cultura popular "pode assimilar novos significados em um fluxo contínuo e dialético" e afirma que "a falta de identidade de concepções do mundo entre o povo e escritor vem de este desconhecer os sentimentos populares". Isto não atinge Borba Filho, pois ele se identifica com esta cultura, sendo também um defensor dela. Daí o seu engajamento a partir da compreensão de que através da cultura popular recebemos lições de resistência, sendo necessário evitar a cisão com esta cultura, o que representaria um fator de empobrecimento (BOSI, In. VALLE; QUEIROZ, 1988, p.25-33). Borba Filho insere-se neste contexto em que "o povo tem uma sabedoria popular expressa em códigos, dramaturgia, religiosidade, produtos culturais e senso comum" (WANDERLEY, In. VALLE; QUEIROZ, 1988, p.69-70), dados que o autor utiliza como plataforma para escrever seus textos. Às vezes me deparo com escolhas estilísticas, em que tudo se esvanece, apesar de movimentar-se:

Todos os sinos tocando, todas as casas se abrindo, todos os foguetes subindo, a procissão no meio da rua atrás do Bispo, nos andores todos os santos, na frente destacado, o grupo peticionário rodeando o Bispo que foi à procura do Diabo no Ato do Lenhador, não o encontrando; no Pastoril da Catota Gato Velho, não o encontrando tampouco; no cispladim de Nenê Milhaço, e nem aí; na igreja presbiteriana, nem; [...] (SDC, p.24-25). 
Peter Burke, discutindo a cultura popular, reconhece que este nível de cultura sofre um processo de transformação ao longo do tempo e, questionando-a, conclui ser ela a cultura da não-elite, enfim, a cultura das classes subalternas. Para Burke, é nesta cultura que o estilo de natureza coloquial se manifesta com trocadilhos, rimas, aliterações, repetições, contrastes, pleonasmos, redundância, clichês e estereótipos, como roupagem de estórias tradicionais, apresentandose os motivos numa série de variantes. Por isso, textos diferentes são iguais, ou melhor, são transformações uns dos outros, diferentes permutações entre os mesmos elementos básicos (BURKE, 1989):

\begin{abstract}
Nos aromas dos guisados e dos assados do boteco de Guará abancou-se Lonico-Soldador, apelido vindo da profissão; abancou-se na massa das gaitadas e do ruído de copos, garrafas e talheres; na fumaça e no cheiro da cerveja abancou-se; bateu palmas e esperou, abancado, e não teve que esperar muito para tragar o cálice d'Ela, engolindo cuspe grosso e batendo com exagero na caixa dos peitos, a mão espalmada (AMS, p.75).
\end{abstract}

Nesta congruência entre o popular e o erudito, há uma adequação do texto hermiliano à escritura de Rabelais, cuja fonte de inspiração era popular. Recolhendo motivos na corrente popular, determinou um sistema de imagens, assim como a sua concepção de arte. Há em Rabelais, também, resistência em adaptar-se aos cânones e regras da arte literária vigente. A apreensão da cultura popular, manifestada pelas formas de ritos, obras cômicas verbais e diversas formas e gêneros do vocabulário familiar e grosseiro podem ser desdobrados em festejos carnavalescos, paródias, insultos, juramento e outros, assim como em Borba Filho:

[...] e já o Fiscal dava meia volta para descer as escadas quando Caga-Raiva explodiu dois pontos acima pra onde é que o senhor vai? Já se viu maior 
desfeita? Onde é assim que me trata, vem para minha casa, mal dá uma palavra, satisfação nenhuma, bota o rabo entre as pernas e sai à sorrelfa, comigo não camaleão, vamos à ceia (SDC, p.140).

Em Rabelais, os palavrões contribuíram para uma criação de uma atmosfera popular e o predomínio do princípio da vida material, assim como o grotesco, o humor, a sátira e degradações, entre outras categorias e tudo isso pode ser transposto para muitas das histórias curtas hermilianas:

\begin{abstract}
[...] vocês me matam, a tabaca da mãe, é o corno do seu pai, Totó na defesa do medroso, insultando os moleques de dentro do café nas carambolas, na víspora, nas safadezas; nome de mãe era o que mais se ouvia, eu tenho uma em casa e outra na rua na boca dos frescos, pinguelo da mãe caiu e o cachorro engoliu, macaco sobe e guariba desce, é, é o da mãe que padece [...] (GEP, p.106).
\end{abstract}

Também, em Borba Filho, encontram-se vestígios da Idade Média, pois o escritor da trilogia fazia pesquisa desde os primórdios do teatro na Idade Antiga, detendo-se no Medievalismo, que se patenteia naqueles aspectos explorados por Rabelais que, segundo Bakhtin (1987) representava "o princípio da vida material e corporal, como as imagens do corpo, da bebida, da comida, da satisfação de necessidades naturais, e a da vida sexual" (BAKHTIN, 2010, p.16), como em "Sete dias a cavalo" (SDC, p.127-148), texto alegórico que pode ser visto como uma "representação dos vícios em forma humana, isto é, a invenção de figuras realistas extraídas da vida contemporânea e que representam também os Sete Pecados Capitais" (HODGART, 1969, p.171), fato que se apresenta tal como era concebido na Idade Média. Lima (1986, p.41), comentando este texto, associa-o também aos pecados capitais e diz: "as figuras carregam os sinais grotescos dos vícios da danação e 
mais parecem saídas de um quadro de Hieronimus Bosch, como uma advertência quanto aos perigos da tentação"

A representação do pecado da gula se incorpora aos comentários feitos, chamando-se, ao mesmo tempo, a atenção para a riqueza de detalhes. A predominância da nominalização estabelece a enumeração caótica, o que ressalta a marca do dinamismo, determinada pelos polissíndetos, a forma plural, paralelismos gramaticais, semântico e rítmico que transformam o discurso numa imagem de voracidade. Os elementos descritivos promovem flash de efeitos cinematográficos na apreensão dos elementos concretos do real, como pode ser observado:

[...] Pharmácio-Zanoio [...] olhando e vendo em
duplicata as iguarias, o monte de comida, patos e
galinhas d'água, capotes e paturis, rolinhas e nam-
bus, vacas e carneiros, farofas e arrozes, queijos
e frutas doces e babas-de-goma, e o inglês e o de
bacia e o de rolo e refrescos e vinhos e águas. De
arroto em arroto, Pharmácio-Zanoio se banque-
teava, enchendo-se, fartando-se, [...] (SDC, p.143).

Já estão mais ou menos clarificadas as tendências da ficção hermiliana. No término deste tópico, vale dizer que o respeito pelo Homem e a instigação para uma tomada de consciência frente aos problemas com os quais convivia, é uma forma de vasculhar também a consciência nacional, o que foi reconhecido por Lúcia Helena, quando se referiu ao discurso literário (HELENA, 1980).

Recorro a Benjamin (2012, p.130 et pas.) para destacar o itinerário do projeto literário de Borba Filho e destacar a seriedade de sua arte, o seu compromisso de escritor em que se explicita a valorização da cultura popular. Benjamin lembra que o escritor tem liberdade de escrever o que quiser, mas a situação social o força a decidir como desenvolver a sua atividade. Para este teórico, "a tendência política correta de uma obra inclui sua qualidade literária - porque inclui sua tendência literária". 
E se a obra literária é caracterizada pela tendência justa, ela terá, necessariamente, todas as outras qualidades, inclusive a de situar contextos sociais vivos e de desenvolver um comportamento prescritivo, pedagógico, ensinando outros escritores a escreverem. Sabendo que as relações sociais são condicionadas pelas relações de produção e vendo o autor como produtor, Benjamin situa a função exercida pela obra no interior das relações de produção, coloca a obra dentro das tendências de uma época, o que permite visar a técnica literária naquele conceito que torna os produtos literários acessíveis a uma análise social. Então, a obra assumindo a sua força combativa, como a produção hermiliana, nas narrativas outras, destaca o plano da linguagem, o poder persuasivo e o seu vigor crítico, que denuncia a representação dos desmandos coercitivos no plano do real.

Mesmo sabendo que nem sempre um escritor é fiel ao que fala e mesmo tendo Borba Filho dito em entrevista: "Eu sou um sujeito contraditório", a sua obra está aí para ser lida e os seus contos são o testemunho das técnicas e tendências que podem ser apreciadas sob variadas perspectivas e em função de tendências e técnicas preestabelecidas.

A técnica literária utilizada por Borba Filho, nos contos, é diversificada, no que sobressai em aqueles elementos que dinamizam a cultura popular na apreensão de uma dialética que, num discurso epocal, referente à vivência de uma ditadura, explicita as verdades de um mundo em transformação, o que clarifica um discurso preexistente, na união de arte e história, comprovando, segundo Benjamin (2012, p.245), que "nunca houve um documento de cultura que não fosse simultaneamente um documento da barbárie".

A tendência destacável é preservar a cultura popular, através de quem, com o uso adequado da técnica, focaliza a sociedade, apresentando imagens do painel de uma realidade desumanizada. A cultura popular, neste ínterim, exerce uma função transformadora, unindo técnica e tendência, utilizando a memória, o imaginário, o simbólico, os valores e as relações do mundo real. O narrador, ao lidar com todo 
este aparato, deixa a sua marca na narrativa e capta-se na sua história, os resultados de uma vivência própria, como no conto "Dom" (GEP, p.58-73), quando depois de todas as peripécias, a personagem se transforma num mágico e o seu último feito, envolvendo a bandeira nacional, provoca o incidente de queimá-la, sem possibilidade de retorno à forma natural e, então "Dom preso como comunista envultou-se, quer dizer, tornou-se invisível: o resto é lenda” (GEP, p.73).

\section{Veículos da cultura popular}

Borba Filho recolhe, na tradição oral ou em outras fontes, elementos temáticos para elaborar suas obras. Utiliza também elementos da cultura popular já tratados por ele como estão em: Espetáculos populares do Nordeste (1966), Fisionomia e espírito do mamulengo (1966) e Apresentação do bumba-meu-boi (1982). A intensa comunicabilidade do texto hermiliano, em grande parte, advém da afinidade do autor com o popular. Obra considerada por Fábio Lucas como importante documento social destaca os contos como "novelas de cunho satírico e intenções de crítica sociopolítica, que aproveitam matéria literária popular do Nordeste", acrescentando que "Hermilo Borba Filho deixa um acervo de obras de grande significação para a literatura e a cultura brasileiras" (LUCAS, 1976, p.96). Mas a cultura apreendida por Borba Filho é a cultura popular que quase sempre resulta da representação social, mantenedora da memória histórica, com o intuito de conservar as raízes do povo e manter atuante a sua cultura. E, à proporção que vai tecendo a sua narrativa, combina:

Realismo e verdade que nascem também da sua escritura ágil, da sua linguagem transfigurada e transformadora, do verbo mágico que reelabora, em termos de desgarrada poesia e beleza, situações, cenas e até escatológicas, da 
manipulação vocabular e que lhe facilita fantásticas e delirantes, feéricas e alucinadas associações de ideias e de imagens (BRITO, 1976, p.16).

A profusão de adjetivos nos coloca frente ao entusiasmo do crítico em relação ao texto hermiliano, o que talvez possa ser resumido, dizendo-se que a ficção de Borba Filho corresponde a uma escritura inovadora em todos os seus aspectos. $O$ trecho retirado do conto 0 morto (SDC, p.115-125) nos coloca na perspectiva de Brito, situação em que o verbo mágico entra em ação, ressaltando a expressividade com elementos cômicos em que a própria morte é tratada com zombaria:

[...] na madrugada descobriram o corpo do inditoso língua-grande, o detrator de Dona Lica, das suas prendadas filhas e do digno proprietário rural Coronel Simeão dos Anjos Benevides Costandrade; o corpo pinicado de bala, tantas que era de ver almofada de bilros, riram uns, penalizaram-se outros, também quem mandou, conselho não faltou, está assim porque quis, e ei minha gente não adianta nada agora o homem é morto, tomou foi na jatoba, fala de um dos mais irreverentes, torna o respeitoso: É chamar a autoridade para as necessárias providências (SDC, p.117).

Interessante identificar a simplicidade de Borba Filho, quando diz pertencer a uma cultura de resistência que inclui a cultura popular, mas aponta Mário Souto Maior, dentre todos os escritores nordestinos, como aquele que mais se tem preocupado com o sentimento popular (BORBA FILHO, 1975).

Cunha (1981, p.31) esclarece que "inovação em matéria de linguagem pressupõe, necessariamente, espírito inovador no pensamento, na cultura", o que respalda o texto hermiliano a partir do suporte da 
visão de mundo popular. Pesquisador nato encara esta atividade como deleite e, falando de Cheiroso, um titeriteiro pernambucano, diz que ele:

\begin{abstract}
[...] praticou um mamulengo de exatas medidas populares, [...]. Com Cheiroso entramos no mundo da marionete popular, selvagem, pura, angélica. Dele partiu a descoberta de um mundo que só me aventurei a explorar agora nessa pesquisa mais poética do que erudita (BORBA FILHO, 1966, p.13).
\end{abstract}

Cheiroso dá nome à personagem central do conto "O perfumista" (SDC, p.97-105), já feito referência: "Era de nome Cheiroso, mestre de mamulengos e extratos, dividindo os dias para as vendas e as noites para os bamboleios [...].” À sua vasta erudição, associa este escritor a uma sensibilidade captadora de todos os matizes vindos da concepção de mundo do teatro de marionetes. Considera o Capitão Boca-Mole, de quem se sente devedor de sua sabedoria:

[...] um deus nesse teatro hierático que é o mais
puro dos espetáculos populares do Brasil, suas
origens perdendo-se no passado cujos diálo-
gos - mistura de tradicionalismo e improvisação
- assemelhando-se à técnica empregada pelos
comediantes da velha comédia popular latina [...]
(BORBA FILHO, 1977, p.21).

Há trechos do conto "O boi" (AMS, p.57-59) retomados do espetáculo popular do Capitão Boca-Mole: "Levante Boi vamos s'embora já deu meia noite já rompeu a aurora."

Impossível querer compreender a maioria dos contos hermilianos desvinculando o autor/narrador do pesquisador do mundo popular. Como classificar um texto hermiliano de pornográfico, se para o autor, cuja imaginação está povoada da visão popular de mundo, 
"a espontaneidade do obsceno nas representações do mamulengo afasta o pornográfico que se lhe queira dar. Provoca o riso e age à maneira de catarse" (BORBA FILHO, 1966, p.127). Mas sendo a literatura uma ficção, não seria exagero enquadrar os contos hermilianos como metaficção, uma vez que este escritor retoma do mundo mágico dos espetáculos populares os motivos para o desenvolvimento de suas narrativas curtas e, assim, preserva a arte popular, ao mesmo tempo em que abre caminhos, ainda pouco explorados, para autores eruditos, dando ele próprio exemplo, no aproveitamento do popular e na sua disseminação, quando o conto "O Almirante", que abre a obra $O$ General está pintando (1973, integra o discurso dos espetáculos populares à literatura erudita: "Senhor Capitão-General já foi à cabanga? Não viste? Quando as fateiras estão tratando os fatos, tripas. Viste? Quando elas cortam a tripa em cima e cortam embaixo aquilo que sai de dentro como se chama senhor Capitão-General? Maniçoba" (GEP, p.1-13).

Retoma o autor pernambucano elementos da "arte comprometida", sendo o seu fazer artístico um compromisso desenvolvido por um projeto literário que abrange o social e o estético. Literatura é a concepção de um mundo que, em não sendo seu, não impede que a ele esteja engajado, o que o faz em forma de denúncia, desenvolvendo, ao mesmo tempo, uma adesão irrestrita ao universo mágico dos espetáculos populares do Nordeste. Sob esta perspectiva, falando sobre mamulengo, opina: "Vale-se [...] o artista popular daquilo que os eruditos chamam de "arte comprometida", lançando mão deste veículo para gritar de público as qualidades e o desassombro daqueles que são humilhados na vida real" (BORBA FILHO, 1966, p.118).

Lembro que esta perspicácia no uso da cultura popular liga-se à ideia que tem de povo: "aqueles que estão marginalizados do progresso e do avanço da economia brasileiros 'carentes' de recursos que vão desde os materiais aos espirituais” (BORBA FILHO, 1975, p.10).

Sobre o Pastoril, Borba Filho o explicita dizendo que era, a princípio, a representação do drama hierárquico do Natal com características 
próprias; perdendo o sentido hierárquico e lírico, transformou-se num gênero popular de representação, conduzido pelo espírito popular (já referendado). Versátil na apreensão deste espírito popular, introduz o autor, na descrição de um enterro, conectado à linguagem popular, partes discursivas próprias do Pastoril, num contexto em que o espaço do mundo real também representa o mundo popular: "[...] nas bodegas os homens sempre cantando chega a morte vai a vida, outro grupo na bacafusada do já tô de munheca inchada de abanar essa bichinha, ditos de Pastoril, noite de Sábado, manhã de morte, tarde de adeus, nas despedidas" [...] (AMS, p.46).

Há um destaque especial às cavalhadas no conto "Sete dias a cavalo", com sete variantes. Neste contexto, destaca-se a primeira alusão ao bode (macho caprípede) que é apresentado por Borba Filho em um de seus ensaios (BORBA FILHO, 1973). No conto, as cores dos estandartes, assim como os bastões com efígies específicas, remetem a um mundo simbólico que se caracteriza pela ambiguidade, situação em que o imaginário se expande num texto que se caracteriza por uma linguagem recheada de pormenores, com predomínio de um tom medieval:

[...] surgiram os bandos, assim como da terra brotados, repentinamente sem pedir licença e os de um lado eram morenos e os do outro eram loiros, um cavaleiro moreno levava um estandarte vermelho e dourado com uma cruz cintilante, um cavaleiro loiro ostentava uma bandeira verde recamada de pedrarias cintilantes e nela estava um macho caprípede e os dois bandos se prepararam com armas nas mãos e as armas eram espadas e lanças, nenhuma de fogo, na primeira investida rolaram duzentas cabeças morenas e formou-se um riachinho de sangue, na segunda o número de cabeças cortadas foi igual para os dois lados, na terceira caíram quatrocentos loiros e todos os morenos, só ficou um que deu um brado 
retumbante e partiu contra os loiros, o macho caprípede desceu da bandeira, ficou empinado nas patas traseiras e vomitou fogo, o cavaleiro moreno transformou-se em zéfiro e desapareceu (SDC, p.129).

\section{Carnavalização nos contos hermilianos}

A representação da literatura brasileira do Nordeste através dos contos hermilianos apresenta um nível de amplitude considerável. o mundo carnavalizado descortina-se para o leitor com uma passagem pela sátira que segundo Hodgart (1969) representa uma postura mental de crítica e de hostilidade causada pelos exemplos imediatos do vício e da estupidez humanos. Próprio da sátira, no plano estético, é encontrarem-se jogos de sons ou de palavras ou de outras relações de linguagem, como pode ser observado no exemplo: "Naquela noite, Quiterinha chamou o promotor, especializado em púberes e impúberes, o promotor foi aos dentros de Diana [...]" (AMS, p.99).

A fantasia, como representação de visão de mundo transformado, interage com o realismo, o que se constitui como a chave da sátira:

[...] o juiz de direito, que se preparava para ir à casa de sua amásia teúda e manteúda, pretextando à legítima que iria a uma reunião na loja maçônica da qual era grau trinta e três, fez uma conchinha com a mão esquerda, destampou o vidro e fez o gesto de encher a conchinha, ouviu o tiro, sentiu uma dor de ficar com a vista escura, quando olhou para a mão esquerda a conchinha era uma cacimbinha [...] (SDC, p. 103).

Há subformas satíricas, dependendo do tema desenvolvido, como a busca do entretenimento associada a festas, a contos populares de 
animais, à inversão do mundo real, como se vê a seguir: “[...] Bernardo deu-lhe as costas e tirou o instrumento para mijar e Trombador arremeteu e deu uma bicada tão grande que o arrancou e as galinhas o pinicaram, Bernardo se esvaindo em sangue, quando o encontraram no fundo da arena já estava frio e teso" (AMS, p.4).

Também são aproveitados, na sátira, elementos escatológicos, obscenidades, pornografias, paródias, comicidades, entre outros, como nesta ilustração:

[...] vi com estes olhos que a terra há de comer o praça ficar nu a mandado de Dom, com aquela bilolinha de menino-deus, que o réu estalou os dedos e de repente o soldado estava com um mangará entre as pernas, muito maior do que o de Benvenuto conhecido em toda a região que dali saiu para fornicar com Quiterinha-Folote e que na volta contou que a dita meretriz quase não o aguentava precisando de muita brilhantina Royal Briar, que o praça declarava que aquele tinha sido seu lavapeito, ancho como uma poimesa, contando a história para quem quisesse ouvir e chegando mesmo a exibir prativai com desmedido orgulho e satisfação (GEP, p.65-66).

Mesmo já tendo feito referência à obscenidade e à pornografia, apresento a visão hodgartiana em que "a obscenidade dentro da sátira quase sempre pode distinguir-se claramente da pornografia, se considerarmos esta última como descrição deliberada dos temas sexuais com o propósito de fomentar o desejo sexual [...]". Hodgart acrescenta: “[...], a finalidade da obscenidade dentro da sátira consiste em reduzir a um mesmo nível todos os homens [...], eliminando as diferenças de classe ou de riqueza" (HODGART, 1969, p.24, 29), conforme o exemplo supracitado, donde já se explicita o processo de carnavalização. 
Na sátira, a política pode ser um dos temas como relação concreta, como se averigua:

[...] o Coronel Aprígio Caldeiras da Costa Aires, no mando e desmando, dando carta e jogando de mão nos despautérios das atas forjadas e dos duplos dos analfabetos na ressurreição de bem umas cem almas necessárias para a maioria absoluta nas eleições do dia seguinte [...] (AMS, p.49-50).

A liberdade de expressão é uma marca satírica, assim como o anticlericalismo e as mulheres:

[...] o Padre como para o batismo, só não largava a pasta com os santos óleos, ia de beata em beata e na testa de cada uma dava um traço e prolongava o traço com ele descendo até o pescoço, ali parando, esperando que a supra dita beata se fosse alijando dos seus vestires e o dedo ia descendo, não tinha mais óleo, mas era como se tivesse, descia o dedo até as partes pudendas e aí já tinha óleo [...] (AMS, p.78-79).

O aspecto mais importante da sátira é o tema, quer seja este a política, as relações sexuais, a insensatez das pessoas, a crítica, a denúncia. Através da sátira se estabelecem o riso, o chiste, a comicidade, os ditos, o ridículo e outros, manifestados como alegoria e fábula, intensificados, muitas vezes, pelo grotesco e pela fantasia:

[...] siá Claudina culatrão subira na vertical e depois na maior velocidade na horizontal se deslocara com as saias levantadas mostrando os rios de varizes, para o norte da cidade e já estava lá flutuando com as mãos para o alto, parecia uma 
santa, por cima do matadouro, rodeada por um fiozinho de luz, direito um cordão de lâmpadas de festa de igreja, só que sem lâmpadas, tinha gente embaixo olhando a aparição, ainda tardaria que os fiéis dela tivessem percebimento da condição [...] (GEP, p.111).

Hodgart informa também que a verdadeira sátira não fixa apenas um momento determinado da história, fazendo do acontecimento uma advertência permanente para o futuro, mas diz a verdade sobre a profundidade da natureza humana, que nunca se transforma (HODGART, 1969), o que é comum no texto hermiliano, acrescido de um irônico tom jocoso:
[...] e ninguém queria trabalhar porque quem tra- balhava era sinal de que estava apto e se estava regimentando tudo quanto era homem em con- dições para as batalhas de Lomas Valentinas, Humaitá, Passo da Pátria, todas aquelas heroici- dades e lá ninguém estava disposto a ser herói, só a pulso (AMS, p.122).

Esta concepção de mundo de Borba Filho, fixada no popular, foi uma contribuição valiosa ao meu projeto de escritura deste livro e, após a apresentação do pensamento de Hodgart (1969), trago Bakhtin (2010 a;b;c; 2008; 1992) e Burke (2010) para analisar alguns aspectos do popular nos contos estudados. O estudioso russo estabelece o entendimento da cultura popular a partir do conjunto de sistema de imagens e concepção artística de Rabelais, acrescido de os gêneros de discurso e a consciência da realidade concreta da linguagem e uma metodologia crítica e inventiva na poética de Dostoiévski e, ainda, o centramento na língua como instrumento de comunicação.

Burke (2010) interessa pelo modo de apresentar o povo como veiculadores da cultura. Estes estudiosos, indiretamente, remetem aqueles que se interessam pelos "efeitos" da cultura popular, para 
buscarem novas fontes de pesquisa. Com base na discussão de Bakhtin, posso dizer de Borba Filho que, através da carnavalização, o sentido se modifica para se transformar "nas formas fundamentais de expressão da sensação popular do mundo, da cultura popular" (BAKHTIN, 2010 a, p.5).

Detenho-me num aspecto da carnavalização como a profanação do sagrado, através da paródia quando o narrador hermiliano, como sempre, enfatiza os detalhes, o que confere ao texto um tom de comicidade:

\begin{abstract}
[...] entrou num casamento na Baixa da Égua e perguntou há vinho?, como resposta obtendo um copo de cerveja, pois de álcool só havia cerveja, recusou a cerveja com cara de reprovação, pediu dois copos: um com água e outro simplesmente vazio, quando passou a água do copo com água para o copo sem água ela neste último se transformou num líquido cor-de-rosa, ele disse é vinho, trouxeram mais copos, o mesmo líquido róseo, todos os que provaram e beberam disseram que tinha mesmo era gosto de sangria, mas não se podia negar a cor (GEP, p.70).
\end{abstract}

Também como ilustração de carnavalização, podem ser apresentados:

a) O uso de palavrões: "os versinhos safadosos Dona Lica é mulher de sina curta / Tem três filhas todas três deram pra puta / O marido queima-queima seu furico / Dia e noite vivem todos nessa luta [...]" (SDC, p.115);

b) A utilização de imagens grotescas: “[...] ridículo continuar a chamá-la de Donzela, [...] justificação de nome, os homens diziam precisou ter estômago com aquela sujeira, o fedor acre, o riso 
dos dentes sujos, deve ter gosto de coco podre no mínimo [...]" (GEP, p.42);

c) Vestígios dos ritos do prazer sensorial e sexual: “[...] discutindo horas seguidas as propriedades diuréticas, cardíacas, circulatórias, intestinais, figadais, olfativas, palatais, sexuais, toda ela magra como uma tábua de engomar, mas ativa de cama e mesa, [...]" (SDC, p.143).

d) A morte como um processo de renovação: "É tísica, diziam, até que veio a morte, num fim de tarde, num meio de verão, com cigarras e cheiro de mel, só: [...]" (SDC, p.58);

e) Imagens construídas pela interação de polos opostos: “Conversas dos magníficos e dos pés-rapados, que a casa estava cheia deles: promotor, juiz de direito, tabelião, escrivão, delegado de polícia [...] bedegueba, calunga de caminhão, Mateus, mestre de samba-de-matuto, senhoras da melhor sociedade local [...]" (AMS, p.64).

A característica destacável do discurso hermiliano é o nível de ambiguidade e de ambivalência, marca determinante das imagens do carnaval que, segundo Burke (2010), eram ambíguas por apresentarem sentidos diferentes para diferentes pessoas e ambivalentes por apresentarem diferentes sentidos para a mesma pessoa. Burke discute ainda a facilidade de "documentar a atitude das classes altas, para as quais estas imagens simbolizavam caos, desordem, desgoverno", e lembra que "menos claro é se o povo achava ruim esse "mundo de pernas para o ar"' (BURKE, 2010, p.257). Borba Filho, nas várias situações de um mundo carnavalizado, apresenta "a palavra com seu tema intacto, a palavra penetrada por uma apreciação social segura e categórica, a palavra que realmente significa e é responsável por aquilo que diz" (BAKHTIN, 1992, p.196), embora no cerne de um discurso que, ao mesmo tempo em que é ambíguo, pode ser visto às vezes como ambivalente, estando, pois, na dependência das dobras críticas desenvolvidas pelo narrador. 
Para fixar bem a noção de carnavalização, recorro ainda a Bakhtin:

É uma forma sincrética de espetáculo de caráter ritual [...], apresenta diversos matizes e variações dependendo da diferença de épocas, povos e festejos particulares. O carnaval criou toda uma linguagem de formas concreto-sensoriais simbólicas entre grandes e complexas ações de massas e gestos carnavalescos [...]. É essa transposição do carnaval para a linguagem da literatura que chamamos carnavalização da literatura (BAKHTIN, 2008, p.139).

Selecionei "Episódio de um homem bissexto" (GEP, p.14-18) para destacar um discurso que se ambienta, através de sua linguagem, no âmbito de uma literatura carnavalizada. Neste conto, agrupam-se vários elementos temático-composicionais e categorias estéticas, de onde resultam elos mediadores, num contexto em que a inserção de um mundo estético, que é dado ao autor construir, se relacionará com o mundo objetivo em que vivemos (GOLDMANN, 1967).

O protagonista do conto em estudo, pela sua excentricidade, é um ser carnavalizado. Isolado de todos, morando num casarão afastado, de aspecto mal-assombrado, com uma mulher albina. Só era visto uma vez por ano, precisamente numa quarta-feira de cinzas, desfilando pelas ruas vazias da cidade: "trajava uma roupa verde-escuro, camisa listrada, camisa e gravata amarela, chapéu cor de chocolate, sapatos brancos, ritmando seus passos com uma bengala retorcida, entrava ano saía ano" (GEP, p.14).

As imagens carnavalescas são plurívocas. A bengala retorcida, utilizada para ritmar os passos da personagem pode, nesta situação contextual, funcionar como cetro do rei do carnaval; é utilizada também como ponto de apoio, como instrumento de defesa e pode conotar, ainda, uma simbologia fálica. É com a ponta da bengala retorcida que bate à porta de Doninha-Cu-de-Pato; com a ponta da bengala 
empurra-a para a cama e ao desnudar-se faz malabarismos com a bengala, soltando-a, apenas, para o ato do amor. A bengala também atua como um talismã que preserva a vida, pois a personagem morre quando dela se desprende.

Doninha foi a única pessoa que o ouviu falar e ele o fez em tom queixoso e pedinte, o que provocou a piedade de Doninha e a sua aquiescência ao pedido, já pronta para o ato sexual:

\begin{abstract}
[...] chamou-a com os braços estendidos, só então ele largou a bengala retorcida, [...] deitou-se em cima da mulher, foi introduzido pela mão hábil, ficou parado, ela mexeu-se, ele gemeu baixinho, depois mais alto, ela sentiu seu líquido, ele ficou inerte, ela deixou, esperou, não sentia seu coração, seu hálito, seu calor, empurrou-o, os olhos abertos, ela reparou que eram verdes, e verde foi ficando todo o seu corpo glabro e alvo, alvo e verde, verde, cada vez mais verde, um calango pensou ela e começou a gritar e gritou mais ainda quando viu aquela mulher gorda, alvíssima, de cabelos brancos e de olhos azuis, na porta do quarto (GOLDMANN, 1967, p.18).
\end{abstract}

Além do estranhamento em nível do discurso e da história; neste texto, entra em cena todo o campo da comicidade séria, recurso constante na literatura carnavalizada, além de todo um ritual que culmina com a representação do corpo grotesco: "as costelas apareciam como as de um esqueleto, as coxas eram tão finas quanto taquaras, não tinha um pelo no corpo, inclusive no púbis, o pênis duro não seria maior que um dedo indicador" (GEP, p.18).

Destacam-se, ainda, neste texto, a presença do elemento fantástico e o realismo grotesco nos prelúdios do ato sexual, e após a sua realização, a linguagem ambígua e ambivalente e a deformação do corpo da personagem. Acrescentem-se o cromatismo, o código linguístico 
transformado em símbolo do insólito, o processo de mudança e transformação, tudo inserido num plano que reflete a carnavalização na literatura.

Existe, ainda, a junção do sexo e da morte, presenças constantes do discurso literário carnavalizado. Neste contexto, o sexo determina prazer e morte (aproximação de Eros e Tânatos), de onde emana a função carnavalizada. É como se se pudesse afirmar com Bakhtin: "[...] tudo renasce e se renova através da morte" ou ainda dizer "o fim deve estar prenhe de um novo começo", da mesma forma que "o nascimento é prenhe de morte, a morte de um novo nascimento" (BAKHTIN, 2008, p.142).

Após refletir sobre este texto como literatura carnavalizada, cabe a pergunta: quem era mesmo o homem bissexto e a mulher gordíssima? O narrador não reflete, mas faz refletir, embora, na carnavalização, não se encontre uma resposta definitiva. Concorre também para isso a ambiguidade e a ambivalência da carnavalização. E, segundo Bakhtin (2008, p.144): "São muito típicos do pensamento carnavalesco as imagens pares, escolhidas de acordo com o contraste (alto-baixo, gordo-magro, etc.)". Posso acrescentar ainda: "Trata-se de uma manifestação específica da categoria carnavalesca de excentricidade, de violação do que é comum e geralmente aceito; [como prática do sexo], é a vida deslocada do seu curso habitual".

Concluo esta amostra com Pires $(1989$, p.86) para quem esta teoria é aplicável a textos e autores de épocas diferentes, de correntes e estilos diversos e "se presta muito a uma forma de contestação social e política”, vertente bem explorada por Borba Filho, mormente no que se refere à contestação, como um procedimento textual que enfatiza a cultura popular, onde o sincretismo permeia, fortalecido pelo modo de fabular do povo, tão frequente em sua ficção.

Nesta busca de peculiaridades de cultura popular, Borba Filho contribui para ampliar a lista de escritores ecléticos, como Gregório de Matos, Oswald e Mário de Andrade, José Cândido de Carvalho, Ariano Suassuna, Patativa do Assaré, Leandro Gomes de Barros, Guimarães 
Rosa e tantos outros, [só para me deter em autores brasileiros]. Também este escritor combina tendências estéticas, aparentemente díspares, quando "o maravilhoso, fantástico, paródico, carnavalizado, configura-se como realismo grotesco" (IANNI, 1983, p.101). E os textos, em sua ambivalência e ambiguidade são representações de variadas invenções literárias, liberdades poéticas, criações e recriações de linguagens, que têm a ver com o real vivido, histórico e com a fantasia e a criatividade do autor. Então, "o real aparece como é: desproporcional, descomunal, carnavalesco, grotesco" (IANNI, 1983, p.93), o que pode ser ilustrado com um texto, cujo tema é a avareza e a culminância é a morte da personagem, situação em que o narrador atinge o ápice de sua imaginação: "[...] Barriga-de-Ouro estendido em cima do balcão, a barriga aberta ao longo, cheia de dinheiro, dinheiro entrando, dinheiro saindo? não havia uma gota de sangue, somente dinheiro, dinheiro e merda" (AMS, p.57).

\section{Atuação popular da cultura}

Borba Filho procura tecer, na trama da suas narrativas curtas, alguma particularidade local, maneiras de sentir e viver o real do povo, captando do imaginário popular subsídios para estruturar sua trilogia de contos. Embora não se limitando apenas a este mundo imediato, próximo dele, pois a "fantasia" ostenta a contestação das arbitrariedades cometidas pelos poderosos e os problemas sociais com que o povo convive [aliás, os de sempre] se apresentam como ironia. Capta-se neste escritor o tom irônico, o deboche, a crítica e a denúncia como atributo de sua ficção [a que já fiz referência], fazendo que tudo por ele focalizado represente "a chave insubstituível que dá acesso à inteligência da cultura popular nas suas manifestações mais poderosas, profundas e originais" (BAKHTIN, 2010 a, p. 418). 
Apresento a área da alimentação, cujas imagens, na sua prodigalidade, abarcam o comer e beber, mesclados às do corpo grotesco, à Rabelais:

\begin{abstract}
[...] nos acepipes que até dá gosto esmiuçar: um grande pernil de porco para a hora apropriada, travessas de galinha cabidela, lombo ao molho de ferrugem, um cozido de camorim de água doce e outro de pitus do Una, um aferventado de peru, pirões, farofas de bolão e de manteiga com ovos e com azeitonas, arrozes-de-leite, ligado, ao forno, solto, feijão mulatinho, e feijão-chocha-bunda, de sobremesa doces de calda e de cascão, batidos e em rodelas, queijos de mochila e de coalho, mesa digna, do nome de mesa, todos muito satisfeitos na regalia, [...] tudo aos poucos se diluindo no vinho Alcobaça do legítimo, a teúda e a manteúda era bem tratada [...] diziam com a boca cheia nos borrifos e nos goles, queijo-do-reino com doce de mamão ralado [...] (SDC, p.119-120).
\end{abstract}

De acordo com a tradição, é comum o povo se banquetear em velórios, principalmente em espaços interioranos, onde as pessoas, como parasitas, interessadas nos comes e bebes, transformam tudo em festa popular quando as conversas, livres e descontraídas, tornam-se acessíveis ao jogo e à alegria. Borba Filho apreende essa visão popular e, como Rabelais, na descrição do banquete parece imaginar que as imagens do banquete são universais e "misturam-se organicamente às noções de vida, morte, renascimento e renovação [...]. Enfim, penetra -as a ideia do tempo alegre que se encaminha para um futuro melhor, que mudará e renovará tudo a sua passagem" (BAKHTIN, 2010a, p.264):

[...] na sala os comentários era até moço, o safado, isto em voz baixa, só a língua o matou, a língua, foi a sentença, eu sendo ele ontem não teria ficado na 
rua, ficou para morrer, atenções desviadas para as bandejas que chegavam com os tiragostos: torresmos, colhão-de-porco, miolos dourados, fígado de alemão, bagre, sardinha de barrica, tudo muito do salgado na salmoura pra puxar o Conhaque de Alcatrão de São João da Barra e a cerveja gelada [...] (SDC, p.119).

Referencio a imagem grotesca do corpo em Borba Filho, suas fontes e a atualização do estilo rabelaisiano associados ao baixo material e corporal. Como afirma Bakhtin (2010a, p.265): “o exagero, o hiperbolismo, a profusão, o excesso são, segundo a opinião geral, os sinais mais marcantes do estilo grotesco". Apresentando a opinião de Bakhtin, dispenso a cronologia e a espacialidade do grotesco tais como são discutidas por Kayser (1986), para me deter no texto hermiliano que se coaduna mais com o pensamento bakhtiniano. O grotesco não pode ser desvinculado da sátira e do fantástico, ou mesmo do realismo mágico, conforme defende Borba Filho. Tudo isso são dados comuns da cultura popular, pois o povo quando não consegue encontrar, no mundo objetivo, explicações para expressar a sua concepção de mundo, na organização do seu universo estético, vale-se do fantástico ou da sátira para a sua representação. O conto "Hierarquia" (SDC, p.125) tem como personagem um soldado que tendo "perdido a parada" utiliza um preparado para curar-se da impotência, mas "continua a pedra de gelo costumeira". Como os elementos mais destacáveis do corpo grotesco são o ventre e o falo, funcionando como objetos prediletos da hiperbolização, observe-se no texto hermiliano como se apresentam num amálgama fantástico-satírico:

[...] nada impedindo que o seu órgão quente, mesmo repelido pela frieza, se arrastasse pelo quarto, só cobra, e cobra grande, bem grande, bem grandona, já no corredor, empinando-se a cabeça com os seus delicados compartimentos e em cada 
um dos compartimentos tampas de cervejas, pontas de cigarro, pules de jogo-de-bicho, papel de jornal breado, algodão de dentista, gazes e esparadrapos, uma esponja do mar, cascas de aruá, uma aliança de latão; [...] recolheu-se o órgão, ninguém diria, tudo como se nada fosse, murcho todo ele, [...] (SDC, p.1-2).

O corpo grotesco relaciona-se com aspectos sexuais e quase sempre são destacadas outras partes do corpo. A boca, como está em Rabelais, se apresenta na sua função devoradora e, mesmo não estando muito aberta, é sugadora, o que faz movimentar outros órgãos, tal como se apresenta na ilustração abaixo:

[...] e viu o Anspeçada agarrado tal carrapato aos peitos carnudos e ebúrneos de Ariqueta-Noites-eDias, e os peitos na mamada ora cresciam oram diminuíam, eram uma melancia empinada ou uma laranja redonda conforme a chupada, o que o Anspeçada bebia nos peitos saía que nem repuxo luminoso por sua estrovenga, só que se desfazia mesmo no ar, sem borrifos [...] (SDC, p.2).

Com uma fixação especial na genitália, o corpo grotesco liga-se ora às injúrias, ora ao riso, ao mesmo tempo que estabelece a ironia, como uma característica própria da linguagem representativa da cultura popular:

[...] e viram que sentado no chão, de pernas abertas, o Alferes expunha os quibos besuntados de azeite de carrapateira quente, os quibos demasiadamente inchados, soltou o punho e mergulhando uma peninha de galinha, macia, dentro de uma lata de manteiga vazia com ela besuntou os quibos, soltando pequenos gemidos (SDC, p.10). 
A caracterização do corpo grotesco é palpável e constante, apresentando-se, às vezes, como contestação ao monopólio estrangeiro, prestando-se, assim, a uma visão crítica do mundo real, como no texto abaixo:

[...] o Diabo não era encontrado [...] até que [...] foram acudidos por um trêfego, buliçoso, chocarreiro cara de pau, de nome Mosquito, que aos pulos e cambalhotas no meio da poeira conduziu-os à presença do Gerente da The GreatWestern of Brazil Railway Company Limited [...] (SDC, p.25).

Ao encerrar este tópico, aplico às narrativas curtas de Borba Filho palavras de Bakhtin que se coadunam com o projeto literário hermiliano: "Nos pastiches desse gênero, o desmembramento do corpo, acompanhando o da sociedade, constitui um fenômeno dos mais notáveis" (BAKHTIN, 2010a, p.307).

O pastiche, neste contexto, é a representação da própria vida, uma vez que os contos hermilianos trazem à tona uma literatura corajosa que se vinga da hipocrisia do mundo real, representando, no plano simbólico, seres verdadeiros a quem se poderia até atribuir uma identidade. Em torno desta literatura, o leitor pode aderir a uma arte cuja representação social consiste num compromisso com valores éticos, uma deontologia de ponta, através de um discurso espetacular, que põe a vida em situação fronteiriça com a alteridade, para localizar a diferença que pode acontecer na sociedade, com nexos da história, desdobráveis em possibilidades, identificáveis no espaço da ficção. 


\section{O mundo cômico popular}

A cultura popular não se dissocia do mundo cômico popular, mas irradia a comicidade, como um manancial que representa "visões de mundo" compatíveis com o estilo popular. Mesmo levando-se em conta que "o mundo não coincide totalmente com o discurso sobre ele; qualquer estilo existente é limitado, só se pode usá-lo com reservas" (BAKHTIN, 2010b, p.367), há no escritor pernambucano uma tendência específica que, caminhando pelos labirintos da fantasia, vem à tona enriquecida pelos princípios que regem a cultura do povo. Há muitos elementos que, nos contos hermilianos, contribuem para a cultura da comicidade. Na visão bakhtiniana, a cultura cômica popular é infinita e heterogênea nas suas manifestações. Na esteira de Bakhtin (2010 a, p.50 et pas.), o teórico questiona o riso desde a antiguidade até o século XX. O seu estudo, aplicado a Rabelais, enfatiza a Idade Média. E este estudioso deixa claro que outros interessados no estudo do riso muitas vezes não reconhecem que "o aspecto cômico é universal, ele se propaga a todas as coisas". Aplica-se às narrativas curtas de Borba Filho este enfoque bakhtiniano e verifiquem-se, neste autor, as variadas modalidades do mundo cômico popular. A acuidade de Borba Filho no aproveitamento de tudo que representa a visão cômica popular do mundo não tem como motivação um tempo/espaço específico, uma vez que Borba Filho, em sendo um pesquisador nato, sabe como utilizar os meios que lhe convêm. Sua pesquisa tem um longo percurso, no tempo e no espaço, desde pesquisa sobre teatro (Commedia dell'Arte), espetáculos populares, a arte num sentido genérico, a literatura de cordel, a literatura oral e a literatura matuta, assim como a literatura erudita, com representações de várias culturas, que extrapolam o meramente nacional e perpassa pelo midiático, como midiatização dos recursos por ele utilizados enquanto pesquisa. Nos textos, inclusive, há uma tendência de apreensão de valores sociais padronizados. O cômico popular, no Brasil, tem início com Gregório de Matos, pois a sua poética fescenina tem rizomas que se introduzem em variados 
autores e Borba Filho soube utilizar um estilo "desabrido", que remete para o poeta baiano, não ficando, pois, isento de sua influência.

Situo as imagens e a sua relação com as formas dos espetáculos, relacionando-os entre si no conto "Hierarquia" (p.1-25). Nele, a praça pública é substituída pelos corredores de um convento e o estilo hiperbólico está centrado em enumerações e antíteses, quando há uma inversão do real entremeada por alusões históricas, o que permite enveredar pelo extratexto na esteira de Lotman (1978, p.102), para quem "a estrutura extratextual está tão hierarquizada como por completo a linguagem da obra artística". Eis o texto a ser trabalhado:

Era a um passo: tinha somente oito quilômetros de corredor e depois meandros labirintos, túneis, cavernas, tudo datando da época dos flamengos, o Sacristão à frente com uma tocha na mão, legítimo capa-e-espada, muito próprio para assombrações e sandenices de frades libidinosos, perjúrios, excomungados, assassinos, havia morcegos voando dum pra outro lado, ratos de esgotos, baratas cascudas, um bafio esquisito, e à proporção que o túnel principal se alargava o exército ouvia uma voz seráfica entoando com raiva:

\section{É desde a Semana Santa}

Que essa desgraça não canta

Vem aqui só perturbar (SDC, p.16).

Alguém poderá pensar em Borba Filho como um autor divertido ou extravagante. 0 conteúdo de seus contos, no entanto, vai mais fundo. Além das várias categorias literárias, postas em ação, avulta, através delas, o compromisso social, a preocupação com a vida. Daí o caráter de sua ficção ser confiável, no que se refere à prática dos valores cultivada pelo autor, donde posso recorrer a Bakhtin, para dizer com ele: 
"somente o riso, com efeito, pode ter acesso a certos aspectos extremamente importantes do mundo" (BAKHTIN, 2010a, p.57). Encontra-se, na literatura de Borba Filho, o riso ligado a várias épocas, mas o destaque maior é o da cultura cômica da Idade Média, o drama da vida corporal, participando do grande corpo particular da espécie, inseparável do mundo, impregnado de elementos cômicos, fundindo-se com a terra que absorve e dá luz, tendo como traço distintivo sua ligação indissolúvel e essencial com a liberdade, transmitindo uma sensação social, universal (BAKHTIN, 2010a). Ainda em relação a Borba Filho, há, na trilha da sua ficção, preocupação em comum com outros que o antecederam, o que no rasto de Schneidermann (1980, p.93) posso afirmar: "a importância atribuída à tradição popular, a concepção do riso com algo fundamental para compreender a natureza do homem e a relação entre o riso e os fatos da linguagem" que elaboram o status do autor, situando-o em destaque na literatura brasileira do Nordeste, e, por extensão, na literatura do Brasil.

O conto "Auto-de-Fé do Pavão Misterioso" (GEP, p.86-96), [deixo de lado as relações transtextuais com o folheto de cordel do poeta José Camelo de Melo Resende], ressalta o compromisso social e outros semelhantes, incluindo os dados expostos no parágrafo anterior:

[...] onde estava o povo? se indagava ali pelo carnaval estivera e vira cores e cheiros, alguns desregramentos, gente muita, todo mundo com todo mundo [...] a fome é igual mesmo que as pessoas sejam desiguais [...] só podia ser festa, festa era [...] bebeu, comeu do seu e comeu o dos outros (GEP, p.87-88).

Estão presentes elementos da natureza: montes e vales, colinas, outeiros, chãs, cristas, chapadões, bosques e capoeira, riachos e alagados, várzeas, canaviais. E elementos cômicos: "eu não sou capão de quenga que choca, cria pinto e passa galo, e deu-lhe uma daquelas enxaquecas iguais às de cobra que morre mordendo o rabo" (GEP, p.94). 
A tradição popular se manifesta através da enumeração de personagens dos espetáculos populares:

[...] um Capitão de Fandango com sua espada flamejante em seus passos de dança, um Capitão de Bumba-meu-boi montado em seu cavalo-marinho, [...] o Cabo 70 com um deus-me-perdoe, [...] um Bedegueba com um cipó-pau retorcido, [...] um Rei de Reisado, [...] uma Rainha de Maracatu com uma enorme coroa e um cetro, [...] um Guerreiro de tacape $[. .$.$] (GEP, p.95-96).$

A compreensão da natureza do homem, em Borba Filho, quase sempre teria que estar associada à sensualidade, ao sexo e ao erotismo, quando o riso revela de maneira nova o mundo alegre, lúcido, com aspectos decorativos e alegóricos, permeados de obscenidade ambivalente:

Ana-De-Todos-Nós de saias levantadas e coxas à mostra, vez de vez uma nesga da mata e isto já era um conforto para os assistentes, Ubaldo sempre à frente com o facho, era o cajado o facho, as portas se abrindo e as mulheres dos magníficos se persignando com muito respeito, os magníficos eles mesmos aparentando sisudez mas lambidos de satisfação não pelo cajado mas pelo vale de Ana-De-Todos-Nós e nisto Ubaldo se comprazia e agradecia em grandes, enormes curvaturas, e toda vez que ele se curvava o facho luminoso abria na terra um grande círculo azulado e no círculo dançavam gnomos que naquela região tinham vivido havia muitos milhares de anos antes de emigrarem para o frio e tudo terminava de repente com Ana-De-Todos-Nós abraçando-o, nua, nus, está fazendo frio, voltava a dormir, enquanto o sol descrevia a sua curva e a terra ficava firme, imóvel, esperando a noite (AMS, p.25-26). 
As personagens de Borba Filho, como as de Rabelais, são espetaculares e a centelha da comicidade brilha sempre nessa categoria, através do suporte da linguagem, o caráter universal do riso ridicularizando todos os estados da vida, estabelecendo-se, às vezes, as formas reduzidas do riso: "humor, ironia, sarcasmo, etc" (BAKHTIN, 2010b, p. 103):

\begin{abstract}
[...] o Vitório-Barbado saíra-se com esta de que você deve se candidatar, ninguém mais discursador e o que se requer para vereador é uma boa ponta-de-língua, nisto ninguém leva a melhor, botas todos eles no bolso, aqui dentro da barbearia és assim, imagina na praça pública, pensa só na intendência (AMS, p.73-74).
\end{abstract}

Como intérprete da consciência popular, o mundo do riso está aberto a novas interações, em que o tradicional se alinha ao lado do moderno, permitindo, graças ao conhecimento que Borba Filho tem da cultura popular, que muitos de seus contos possam se comunicar com outros trechos representativos do cômico popular como, por exemplo, os de Gógol, autor de quem Bakhtin (2010c, p.437) afirma: "Gógol dá atenção particular às gesticulações e à fonte de injúrias sem desdenhar de qualquer particularidade específica do discurso cômico popular". E acrescenta: "Para este fim servem a dança desenfreada, os traços bestiais que aparecem no homem, etc".

Pode-se transferir esta afirmação para Borba Filho, ilustrando com um trecho em que o tema é a tortura, situação instauradora da ironia:

[...] quem interrogava era Costinha, o vate langoroso das valsas dançadas no Clube Literário recitando, entredentes, para a dama nunca morrer assim, num dia assim, ágil na inquirição, em funções de escrivãs da polícia, se Zumba-Dentão suava ele suava mais ainda, pulava na ponta dos pés, tomava goles de gasosa de bolinha, arrotava fofo, incansável perquiridor, quer perder o dente? (GEP, p.122). 
Reconheço que a cultura popular, tal qual se apresenta em Borba Filho, quando postada em seus contos, ela se põe naquele âmbito em que "a significação dos elementos surge nas suas relações" (LOTMAN, 1978, p.87), relações com os referentes representativos de extratextos desdobráveis em "visões de mundo", por onde perpassam aspectos sociais, psicológicos, políticos, históricos, religiosos, referentes que se intercruzam como incentivo para instaurar uma semiose que aponta para uma fonte de saberes e vivências, repassados de um texto a outro, incluindo a retomada e/ou repetição de outros discursos, signos prevalentes que estão sob a égide de uma semiótica da vida, para dar sentido à existência. 